\title{
End of life, year after year after year
}

Previously published at www.cmaj.ca

A fter Fred (as we'll call him) was diagnosed with an inoperable tumour the doctors told him he had perhaps six months to live. A merchant seaman, Fred decided to spend his savings enjoying himself while waiting for the end.

More than eight months later, Fred showed up at a hospice still dying, but now broke, having spent his savings on what physicians had assured him would be the last months of his life. He stayed at the hospice well past the three-month time limit normally allotted residents — he had no place else to be - but was eventually moved to an apartment with the help of social services. Fred eventually returned, dying almost three years after his six-month, end-of-life diagnosis.

The end-of-life determination sets the agenda for ethicists and physicians who counsel patients as they make decisions based on a presumably foreshortened longevity. ${ }^{1}$ Many hospices share the same assumptions as the physicians making terminal diagnoses, limiting client stays to a set number of weeks.

However, the predictions made by clinicians are at best estimates, the validity of which is daily called into question by the Freds who live on past all expectation. There are many: Famously, for example, cosmologist Steven Hawking was given no more than a few years to live when, in his third year at Oxford University, he was diagnosed with amotrophic lateral sclerosis. He lived until 2009, more than 35 years after his initial, rapidly terminal diagnosis. ${ }^{2}$

The assumption that the date a life will end can accurately be predicted has spawned a robust industry of health economists, medical ethicists, physicians and sociologists who set policy guidelines for the last days and weeks of a person's life. ${ }^{3}$ What will dying cost (the patient and the health care system); where should the death occur (at home, at a hospice, in hospital); and what palliative treatment is appropriate for the dying person, are all explored in countless books, journal articles and policy guidelines.

The general rule, informal, but in many instances inviolate, is to keep the person as comfortable as possible and abjure any

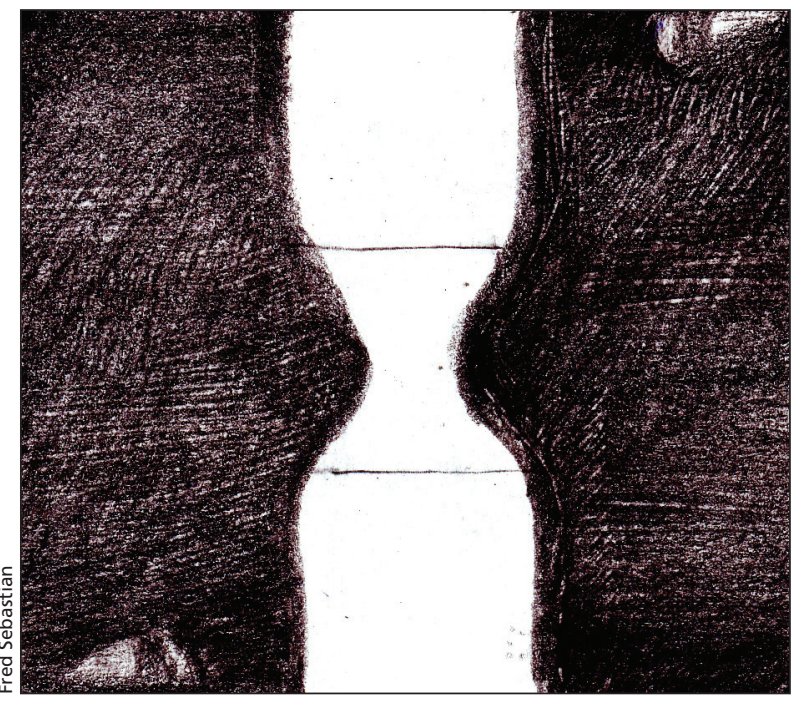

life-prolonging treatment. In this way an end of life determination becomes the handmaiden and overture for another category of medical decisionmaking with real legal currency these days, those based on "futility." "Futility may be a self-fulfilling promise, however, when aggressive medical attention is ignored on the assumption that the end of life is both assured and imminent, or that a patient's condition is without hope of improvement.

As a gerontologist one sees this frequently when a senior with chronic conditions is assumed to be at the end and any nonpalliative treatment will only prolong the dying. Seniors, however, have a habit of confounding physician predictions and living on. ${ }^{5}$ Letting "nature take its course" becomes in such cases an unnatural judgment ending the patient's chances of future life.

Simply stated, the best clinical expectation is often a very bad predictor. Medical decisions based on these expectations may be bad medicine. That patients live longer than expected, sometimes much longer, should be good news. It becomes problematic, however, when assump- tions of early death in "end-of-life decision-making," and "futility" of continued treatment are accepted as determinations that define patient treatment. When that happens, the diagnosis may become the cause of death and not a predictor of it.

\section{Tom Koch PhD \\ Bioethicist}

Vancouver, BC

\section{REFERENCES}

1. Blank RH, Merrick JC. End-of-life decision making. Cambridge (MA): MIT Press; 2005.

2. Hawking S. My experience with ALS. In: Black holes and baby universes and other essays. New York (NY): Bantam Books; 1993. p. 21-7.

3. Field MJ, Cassel CK, editors. Approaching death: improving care at the end-of-life. Washington (DC): National Academy Press; 1997.

4. Wiener RL, Eton D, Gibbons VP, et al. A preliminary analysis of medical futility decisionmaking: law and professional attitudes. Behav Sci Law 1998;16:497-508.

5. Koch T. Mirrored lives: aging children, aging parents. Westport (CT): Praeger Books; 1990.

Have you got an opinion about this article? Post your views at www.cmaj.ca. Potential Salon contributors are welcome to send a query to salon@cmaj.ca.

All editorial matter in CMAJ represents the opinions of the authors and not necessarily those of the Canadian Medical Association. 